\title{
PENERAPAN STRATEGI PEMBELAJARAN AKTIF DALAM MENINGKATKAN MOTIVASI BELAJAR ASWAJA SISWA DI MADRASAH
}

\author{
Dianis Izzatul Yuanita \\ Institut Agama Islam Tribakti Kediri, Indonesia \\ Email: dianisizzatulyuanita@gmail.com
}

\begin{abstract}
Dalam permasalahan pada bidang pendidikan adalah bagaimana guru tersebut dapat pelaksanaan tugas dengan baik, sebab akhir-akhir ini banyak peserta didik yang masih belum memahami pembelajaran Aswaja. Apakah hal ini disebabkan siswa yang masih kurang aktif dalam mengikuti proses belajar atau cara guru dalam mengajar monoton, sehingga siswa menjadi apatis. Dari itu, guru harus memilih metode yang tepat dalam menggunakan strategi belajar aktif (active learning strategy) dimana belajar aktif banyak sekali metode pembelajaran untuk mengaktifkan siswa dalam belajar di kelas atau diluar kelas. Pada penelitian ini, peneliti menggunakan jenis penelitian kualitatif, dengan teknik pengumpulan melalui 1). Wawancara 2). Pengamatan dan 3). Dokumentasi. Selanjutnya analisa data dilakukan: 1) Analisa selama pengumpulan data menggunakan analisa deskriptif, 2) Teknik keabsahan data dengan menggunakan triangulasi sumber data. Hasil penelitian menunjukkan: 1) Penerapan strategi pembelajaran aktif dalam meningkatkan motivasi belajar aswaja di Madrasah Ibtidaiyah Syarifuddin yaitu terdidri atas metode Diskusi, jigsaw, tanya jawab. 2) Peningkatan motivasi belajar siswa ada perubahan diatndai dari keaktifan, kesenganan, dari yang malas menjadi rajin dan antusius, mereka meskipun masih ada sebagian yang motivasinya tidak meningkat. 3) Faktor pendukung: adanya sarana dan sumber belajar yang memadai, minat belajar siswa yang tinggi, dan semangat, waktu pembelajaran dan serta profesionalisme guru aswaja dalam membimbing anak didiknya. Sedangkan faktor-faktor penghambat antara lain sebagian siswa yang masih enggan untuk mengemukakan pendapatnya, waktu pembelajaran dan latar belakang siswa yang berbeda..
\end{abstract}

Kata Kunci : Strategi, Inovasi, Belajar Aktif, Madrasah, Aswaja.

\section{Pendahuluan}

Sesungguhnya kodrat manusia dilahirkan di dunia dengan membawa fitrah. Hal demikian yang membedakan antara manusia dengan makhluk ciptaan lainnya. Fitrah merupakan faktor 
kemampuan dasar perkembangan manusia yang dibawa sejak lahir dan merupakan potensi dasar dalam berkembang. Pendidikan agama Islam adalah suatu usaha sadar dan terencana dalam menyiapkan peserta didik guna mengenal, memahami, menghayati, hingga mengimani ajaran Islam ${ }^{1}$. Ilmu pengetahuan yang diperoleh dari proses pendidikan itu merupakan bekal penting bagi setiap orang dalam menjalankan kehidupan. ${ }^{2}$

Al-Qur'an juga telah menyatakan dalam surat Al-Mujadilah ayat 11 yang artinya: Hai orang-orang beriman, apabila kamu dikatakan kepadamu: Berpanglah dalam majlis, Maka lapangkanlah niscaya Allah akan memberi kelapangan untukmu. Apabila dikatakan: Berdirilah kamu, Maka berdirilah, niscaya Allah akan meninggikan orang-orang yang beriman di antaramu dan orang-orang yang diberi ilmu pengetahuan beberapa derajat. Allah Maha mengetahui apa yang kamu kerjakan. ${ }^{3}$

Berdasarkan ayat tersebut diketahui bahwa untuk beribadah di dunia membutuhkan ilmu pengetahuan karena beribadah tanpa diimbangi dengan mempunyai ilmu pengetahuan tidak akan maksimal dalam pengamalannya. Ilmu pengetahuan yang dimiliki dapat menjadi kunci bagi kehidupan menuju sukses baik di dunia maupun di akhirat. Ilmu pengetahuan sangat penting bagi kehidupan di dunia maupun di akhirat dan ilmu pengetahuan salah satunya dapat diperoleh dengan melalui proses belajar.

Senada dengan itu, Nur Uhbiyati mengatakan bahwa Manusia mengalami proses pendidikan yang didapat dari orang tuanya,

\footnotetext{
${ }^{1}$ Moch Mahsun \& Danish Wulydavie Maulidina. 2019. "Konsep Pendidikan Dalam Kitab Ta'limul Muta'allim Karya Syekh Al-Zarnuji Dan Kitab Washoya Al-Aba' Lil-Abna' Karya Syekh Muhammad Syakir". Bidayatuna: Jurnal Pendidikan Guru Mandrasah Ibtidaiyah, 2 (2), halaman 44-77

2 Muhammad Alqadri Burga. Hakikat Manusia Sebagai Makhluk Pedagogik. Journal of Islamic Education and Teacher Training, ISSN 2657-2362. Vol 1 No 1 (2019).

${ }^{3}$ Kemenag. Al- Qur'an dan Terjemahnya. (Bandung: Syaamilp-Quran , 2012 ). Hal. 543.
} 
masyarakat maupun lingkungan. ${ }^{4}$ Bahkan, pemerintah pun ikut serta dan bertanggungjawab dalam proses belajar masyarakat, khususnya pada waktu masih anak-anak. ${ }^{5}$ Sementara itu, proses belajar mengajar merupakan inti dari proses pendidikan secara keseluruhan dengan guru sebagai pemegang peran utama. Moh. Uzer Usman mengatakan bahwa proses belajar mengajar merupakan suatu proses yang mengandung serangkaian perbuatan guru dan siswa atas dasar hubungan timbal balik dalam situasi edukatif untuk mencapai tujuan tertentu. ${ }^{6}$

Mengingat pentingnya peranan pendidikan bagi pembangunan nasional maka pemerintah berupaya meningkatkan pembangunan dalam bidang pendidikan UU Dasar Negara Republik Indonesia Tahun 1945 Pasal 1 Ayat 3 menegaskan bahwa: Setiap warga negara berhak mendapat pendidikan dan pemerintah mengusahakan dan menyelenggarakan sistem pendidikan nasional yang meningkatkan keimanan dan ketakwaan serta akhlak mulia dalam rangka mencerdaskan kehidupan bangsa. ${ }^{7}$

Strategi pembelajaran merupakan cara untuk membantu suksesnya proses belajar mengajar, karena strategi pembelajaran terdapat desain yang bertujuan untuk mencapai tujuan pendidikan. Akan tetapi harus mengetahui bahwa sebaik apapun suatu strategi pembelajaran tidak akan bisa berhasil apabila tanpa didukung dengan tenaga kependidikan kompeten. Berikut gambaran secara terinci tentang tujuan pembelajaran bidang studi Aswaja dalam kurikulum 2006 adalah:

${ }^{4}$ Nur Uhbiyati, Ilmu Pendidikan Islam, (Bandung: Pustaka Setia, 1999), hal. 9.

${ }^{5}$ Rio Febriannur Rachman. 2019. "Implementasi Kebijakan Pusat Konseling Anak Dan Remaja Di Surabaya". Al-Tazkiah: Jurnal Bimbingan Dan Konseling Islam, 8(2), 77-91

${ }^{6}$ Moh, Uzer Usman, Menjadi Guru Profesional, (Bandung :PT. Remaja Rosdakarya, 1999), hal. 1.

7 Undang- Undang Republik Indonesia Tentang Sistem Pendidikan Nasional, (Jakarta: PT Kloang Klede Putra, 2003), hal. 3. 
1. Membantu peningkatan iman peserta didik dalam rangka pembentukan pribadi muslim, di samping memupuk rasa kecintaan terhadap Islam dan kebudayaannya.

2. Memberi bekal kepada peserta didik dalam rangka melanjutkan pendidikannya ke tingkat yang lebih tinggi atau bekal untuk menjalanikehidupan pribadi mereka.

3. Mendukung perkembangan Islam masa kini dan mendatang, di samping meluaskan cakrawala pandangannya terhadap makna Islam bagi kepentingan umat manusia. ${ }^{8}$

Pelaksanaan pendidikan terutama mata Aswaja membutuhkan pemahaman dalam setiap sub bahasannya, agar guru tidak selalu memdominasi proses jalannya belajar dalam kelas, maka guru pendidikan agama Islam diharapkan mempunyai ilmu pengetahuan dan wawasan yang luas tentang strategi pembelajaran. Dalam pendidikan tidak akan bisa efektif apabila tidak mempunyai strategi pembelajaran dalam menyampaikan materi belajar mengajar dalam kelas.

Kenyataan yang terjadi sekarang, banyak beberapa guru yang ada di madrasah kurang mempunyai strategi mengajar atau pendekatan pembelajaran lain yang dapat disesuaikan dengan materi yang diajarkan, kebanyakan mereka masih menggunakan pembelajaran tradisional dalam melakukan proses belajar mengajar.

Dengan penerapan pembelajaran secara tradisional dengan metode ceramah, dilaksanakan tanpa menggunakan media pembelajaran, pada proses pembelajaran berlangsung situasi belajar mengajar akan terlihat cenderung pada guru. Hal demikian, membuat siswa menjadi pasif di dalam kelas, karena pada saat guru berceramah

8 Ahmad Munjin Nasih dan Lilik Nur Kholidah, Metode dan Teknik Pembelajaran Pendidikan Agama Islam, (Bandung: Refika Aditama, 2009), hal. 10. 
siswa hanya mendengarkan, dalam situasi seperti ini para siswa akan menjadi pasif karena tidak dilibatkan dalam proses belajar.

Siswa menjadi tidak bersemangat dan kurang bergairah terhadap pelajaran tersebut, sehingga siswa banyak yang mengantuk, bermain, dan bahkan bergurau dengan temannya, tidak memperhatikan guru yang sedang menerangkan materi di depan. Pembelajaran tradisional telah secara pasif menerima informasi, menerima kaidah-kaidah seperti membaca, mendengarkan, mencatat dan menghafal tanpa memberikan kesempatan siswa mengeluarkan ide mereka. ${ }^{9}$

Dalam kondisi seperti ini tidak baik untuk siswa, karena tidak membuat siswa untuk berfikir kritis mengeluarkan ide mereka dan siswa hanya menerima informasi yang diberikan oleh guru. Hal seperti ini justru berdampak pada motivasi belajar siswa. Rendahnya motivasi belajar pada siswa disebabkan oleh metode mengajar guru yang dapat menimbulkan kesulitan belajar, guru-guru menuntut standar pelajaran di atas kemampuan anak, dan guru tidak kualifed dalam pelajaran yang dipegangnya. ${ }^{10}$

Seorang guru seyogyanya mempunyai ide atau kreatifitas dalammengetahui permasalahan-permasalahan siswanya guna untuk dekat dengan siswa-siswanya pertama-tama guru harus menggunakan pendekatan individual dalam memotivasi belajar siswa, kemudian guru harus memberikan sangsi bagi siswa yang melakukan kesalahan agar siswa lebih teliti dan berhati-hati dalam semua tindakan dan kemudian guru sebaiknya memberikan bimbingan guna siswa yang kurang faham dengan pelajaran yang telah diajarkan.

9 Siti Solehah. Pengaruh Media Pembelajaran Berbasis Aplikasi Pada Smartphone Android Dilengkapi Game Twoplayer Terhadap Hasil Belajar Kognitif Siswa. journal.unnes.ac.id.

${ }^{10}$ Ahmadi dan Widodo S, Belajar Dan Pembelajaran. (Jakarta:Rineka Cipta, 1991),

Hal.35-38. 
Disinilah guru sebagai pendidik memiliki peran sangat besar, di samping sebagai fasilitator dalam pembelajaran, juga sebagai pembimbing dan mengarahkan peserta didiknya menjadi manusia yang mempunyai pengetahuan luas baik pengetahuan agama, kecerdasan, kecakapan hidup, budi pekerti dan kepribadian baik dan bisa membangun dirinya untuk lebih baik dari sebelumnya dan juga memiliki tanggung jawab besar dalam pembangunan bangsa. ${ }^{11}$

Oleh karena itu, guru harus mengetahui bagaimana situasi dan kondisi ajaran itu disampaikan kepada peserta didik, apa saja yang diperlukan untuk memotivasi siswanya agar mendapatkan pembelajaran yang maksimal, bagaimana meorganisasikan dan mengelola isi pembelajaran, hasil yang diharapkan dari kegiatan tersebut.

Dalam kegiatan pembelajaran terdapat dua kegiatan yang sinergik, yakni guru mengajar dan siswa belajar. Guru mengajarkan siswa harus belajar, sementara siswa belajar bagaimana seharusnya belajar berbagai pengalaman belajar hingga terjadi perubahan dalam dirinya dari aspek kognitif, afektif dan psikomotorik. Guru yang kompeten akan lebih mampu menciptakan lingkungan efektif dan akan lebih mampu mengelola proses belajar mengajar, sehingga hasil belajar siswa berada pada tingkat yang optimal. ${ }^{12}$

Untuk menciptakan lingkungan efektif diperlukannya pembelajaran aktif, yakni suatu pembelajaran yang mengajak peserta didik belajar secara aktif. Ketika peserta didik belajar dengan aktif, berarti mereka yang mendominasi aktifitas pembelajaran. Dengan demikian, mereka secara aktif menggunakan otak, baik untuk menemukan ide poko dari materi pembelajaran, memecahkan persoalan, mengaplikasikan apa yang baru mereka pelajari ke dalam

\footnotetext{
${ }^{11}$ Ahmad Salim. Manajemen Pendidikan Karakter di Madrasah. Tarbawi: Jurnal Keilmuan Manajemen Pendidikan. December 2015

12 Ibid, hlm. 6
} 
satu persoalan yang ada. Dengan cara ini biasanya peserta didik akan merasakan suasana yang lebih menyenangkan hingga hasil belajar dapat dimaksimalkan.

Belajar aktif sangat diperlukan oleh peserta didik guna mendapatkan hasil belajar yang maksimum. Ketika peserta didik pasif, atau sekedar hanya menerima dari pengajar maka akan ada kecenderungan untuk cepat melupakan apa yang telah diberikan. Oleh sebab itu diperlukan perangkat tertentu dapat mengikat informasi yang baru saja diterima dari guru. Belajar aktif adalah salah satu cara untuk mengikat informasi baru kemudian menyimpannya dalam otak.

Hal tersebut di atas dilakukan karena salah satu faktor yang menyebabkan informasi cepat dilupakan adalah faktor kelemahan otak manusia itu sendiri. Belajar yang hanya mengandalkan indera pendengaran mempunyai kelemahan, padahal hasil belajar seharusnya disimpan sampai waktu yang lama. Kenyataan ini sesuai dengan pernyataan Mutiaea yang diberikan oleh seseorang filosof kenamaan dari Cina, Konfusius Ia mengatakan: Apa yang saya dengar, saya lupa. Apa yang saya lihat, saya ingat. Apa yang saya lakukan, saya paham. ${ }^{13}$

Jadi, ketika informasi yang baru, otak manusia tidak hanya sekedar menerima dan menyimpan sesuatu. Akan tetapi juga otak manusia akan memproses informasi tersebut sehingga dapat dicerma kemudian disimpan oleh otak.

Betapapun menariknya materi disampaikan melalui ceramah, otak tidak akan lama menyimpan informasi yang diberikan, karena tidak terjadi proses penyimpanan yang baik. Dengan demikian, dibutuhkannya penggunaan strategi pembelajaran aktif. Terutama bagi pengajar, guna sebagai penyampai materi, strategi pembelajaran

13 Hisyam Zaini dkk, Strategi Pembelajaran Aktif (Yogyakarta: Pustaka Insani Madani,2008), hlm.14-15. 
aktif akan membantu dalam melaksanakan tugas-tugas keseharian siswa.

Atas dasar pemikiran tersebut, maka tidak ada pilihan lain bahwa upaya pengembangan strategi mengajar harus diarahkan kepada keaktifan optimal belajar siswa. Dalam istilah lain, harus mengembangkan strategi pembelajaran yang aktif yang sekarang terkenal dengan istilah strategi pembelajaran aktif (active learning strategy).

A. Fatah Yasin menyatakan bahwa pembelajaran aktif (Active leaning) adalah suatu proses pembelajaran dengan maksud memberdayakan peserta didik agar belajar dengan menggunakan berbagai strategi secara aktif. ${ }^{14}$ Active learning merupakan salah satu aplikasi dari teori konsep tentang manusia menurut Abraham Maslow. Maslow mengatakan bahwa potensi manusia tidak terbatas. Bahkan ia juga memandang manusia lebih optimis untuk menetapkan masa depan dan memiliki potensi yang akan terus berkembang. ${ }^{15}$

Active learning mencoba mebuktikan bahwa semua anak punya potensi untuk berkembang sesuai dengan tahapannya. Dengan strategi ini, potensi siswa dapat terus berkembang dengan dilihat melalui tingkat kreatifitasnya dan tentu saja dalam memecahkan masalah.16

Salah satu langkah-langkah memilih strategi itu adalah seorang guru harus menguasai telnnil-teknik penyajian. Dari sisi dapat dipahami bahwa metode yang tepat dapat dijadikan sebagai alat motivasi ekstrinsik kegiatan belajar mengajar. Dalam hal belajar, Motivasi belajar adalah faktor yang praktis, peranannya menumbuhkan gairah belajar, merasa senang dan semangat untuk belajar. Belajar harus diberi motivasi dengan berbagai cara sehingga

14 A. Fatah Yasin, Dimensi-dimensi Pendidikan Islam. (Malang: UIN- Malang Press, 2008), hlm. 180

${ }^{15}$ Umi Machmudah dan Abdul Wahab. Active learning dalam Pembelajaran Bahasa Arab. (Malang, UIN-Malang Press, 2008), hlm, 123

16 Umi Machmudah dan Abdul Wahab. Active learning ...123-124 
minat yang dipentingkan belajar itu dibangun dan minat yang telah ada pada diri anak.

Dengan adanya motivasi belajar siswa menjadi semangat menerima pelajaran dari guru. Jadi tugas guru disini untuk memberikan strategi pembelajaran yang bisa membuat siswa semangat kembali dengan pelajaran yang diterimanya khususnya pelajaran Aswaja yang di dalamnya banyak memuat kisah-kisah dan sejarah tentang Nabi Muhammad SAW dan khususnya Ahlussunnah Waljama'ah.

Dari paparan di atas, maka penulis tertarik guna mengadakan mengungkap secara lebih luas berupa penelitian strategi pembelajaran aktif dalam meningkatkan motivasi belajar pendidikan agama islam di Madrasah Ibtidaiyah (MI) Syarifuddin sehingga penulis mengambil judul skripsi ini dengan judul: "Penerapan Strategi Pembelajaran Aktif Dalam Meningkatkan Motivasi Belajar Aswaja Siswa Di MI Syarifuddin".

\section{Pembahasan}

1. Penerapan strategi pembelajaran aktif dalam meningkatkan motivasi belajar SKI siswa di MI Syarifuddin.

Active learning strategy adalah merupakan salah satu aplikasi dari konsep tentang manusia. Menurut Abraham Moslow mengatakan bahwa potensi manusia tidak terbatas. Moslow juga memandang manusia lebih optimis guna menatap masa depan dan memiliki potensi yang akan terus berkembang. ${ }^{17}$

Pembelajaran aktif dimaksudkan ialah mengoptimalkan penggunaan semua potensi yang dimiliki oleh anak didik sehingga semua anak didik dapat mencapai hasil belajar yang memuaskan

17 Umi mahmudah M.A Dkk. Active Learning Dalam Pembelajaran, Bahasa Arab, (UIN Malang Press, 2008) hal, 123-124 
sesuai karakteristik peribadi yang mereka miliki. ${ }^{18}$ Di samping itu, pembelajaran aktif (active learning) juga dimaksudkan untuk menjaga perhatian siswa atau peserta didik agar tetap tertuju pada proses pembelajaran. ${ }^{19}$

Pelaksanan strategi aktif learning oleh guru dalam meningkatkan motivasi belajar siswa di MI Syarifuddin ini sudah diterapkan. Hal ini terlihat dari usaha yang bersungguh-sungguh dari guru Aswaja yang berkerja keras untuk melakukan startegi aktif learning tersebut yang semua ditujukkan pada sebuah usahanya yaitu Guru mempersiapkan rencana pelaksanaan pembelajaran (RPP), pembelajaran akan berjalan dengan lancar jika dipersiapkan rencana yang baik.

Melalui rencana yang baik pembelajaran akan aktif, pembelajaran aktif yang dilaksanakan oleh guru di MI ini berjalan dengan baik, pembelajaran aktif adalah mengoptimalkan potensi siswa, memancing siswa, menarik perhatian kepada siswa, pembelajran aktif menjadikan siswa sebagai subjek dalam pembelajaran.

Pelaksanaan aktif learning di MI Syarifuddin yang dijalankan oleh para guru di MI Syarifuddin bisa dikatakan sudah sesuai dengan teoriaktif learning menurut Umi mahmudah M.A Dkk. dalam buku Active Learning. Pembelajaran aktif dimaksudkan untuk mengoptimalkan penggunaan semua potensi yang dimiliki anak didik sehingga semua anak didik dapat mencapai hasil belajar yang memuaskan sesuai dengan karakteristik peribadi yang mereka miliki. ${ }^{20}$

\footnotetext{
${ }^{18}$ Hartono, Suatu strategi Pembelajaran Berbasis Student, disampaiakn seminar Nasional 2005, hlm. 109

${ }^{19}$ Hartono, Suatu strategi Pembelajaran .., hlm. 115

${ }^{20}$ Hartono, Suatu strategi Pembelajaran ..., hlm. 109
} 
Di samping itu, pembelajaran aktif (active learning) juga dimaksudkan untuk menjaga perhatian siswa atau peserta didik agar tetap tertuju pada proses pembelajaran. Namun ada sebagian kecil siswa yang masih belum aktif masih enggan dan malu dan ada juga yang masih ramai dan bikin gaduh kelas, ini bisa jadi karena faktor dari siswa sendiri.

2. Peningkatan motivasi belajar siswa SKI siswa di MI Syarifuddin

Berdasarkan hasil observasi peneliti bahwasanya motivasi belajar siswa pada ummnya meningkat ketika guru menerapkan strategi aktif learning. Bisa dilihat dari keaktifan mereka dengan metode yang diterapkan oleh guru. Selain itu penerapan strategi aktif learning dalam pembelajaran Aswaja di MI Syarifuddin ternyata sangat meningkatkan motivasi belajar siswa, hal demikian ini bisa dilihat dari meningkatnya semangat belajar siswa dari yang sebelum dan sesudah melaksanakan pembelajaran menggunakan metode diskusi.

Adapun respon yang diberikan siswa selama proses pembelajaran Aswaja sangat semangat dan antusias ${ }^{21}$. Hal ini terbukti dengan meningkatnya antusiasme siswa pada proses pembelajaran berlangsung. Meningkatnya semangat dan antusiasme siswa tersebut mulai dari menunjukkan respon siswa terhadap penggunaan metode diskusi sangat maksimal secara umum.

Motivasi tersebut merupakan sebuah perubahan energi dalam diri seseorang yang ditandai dengan munculnya "feeling" dan didahului dengan tanggapan terhadap adanya tujuan dengan paparan teori yaitu dengan menerapkan strategi aktif learning siswa ada perubahana dalam diri mereka masing-masing yaitu:

${ }^{21}$ Wawancara Guru MI Syarifuddin Holifah, 1 Februari 2020 
Sebagaimana pendapat Mc. Donald, motivasi adalah perubahan energi dalam diri seseorang yang ditandai dengan munculnya "feeling" dan didahului dengan tanggapan terhadap adanya tujuan pada objek. Dari pengertian yang dikemukakan Mc. Donald ini mengandung 3 elemen penting:

a. Bahwa motivasi itu mengawali terjadinya perubahan pada energi diri setiap individu manusia. Perkembangan motivasi akan membawa beberapa perubahan energi dalam sistem "neurophysiological" yang ada pada organisme manusia. Karena menyangkut perubahan energi manusia, penampakannya akan menyangkut kegiatan fisik manusia.

b. Motivasi ditandai dengan munculnya, "feeling", afeksi seseorang. Dalam hal ini motivasi relevan dengan persoalanpersoalan kejiwaan, afeksi serta emosi yang dapat menentukan tingkah-langkah pada siswa.

c. Motivasi akan dirangsang karena adanya tujuan. Jadi motivasi ebenarnya merupakan respons dari suatu aksi yakni tujuan. Motivasi memang muncul dari dalam diri manusia, tetapi kemunculannya karena terdorong oleh adanya unsur lain, dalam hal ini adalah tujuan. Tujuan ini akan menyangkut soal kebutuhan. ${ }^{22}$

Menurut Muhaimin berdasarkan sumbernya, motivasi dapat dibagi menjadi dua macam, motivasi yung datang dari dalam diri paserta didik (instrinsik) dan motivasi yang datang dari lingkungan yang berasal dari luar diri peserta didik (ekstrinsik). ${ }^{23}$

a. Motivasi Instrinsik

Jenis motivasi ini timbul sebagai akibat dari dalam diri individu sendiri tanpa adanya paksaan dan dorongan dari

22 Sardiman A.M., Interaksi \& Motivasi Belajar Mengajar, (Jakarta: PT. Raja Grafindo Persada, 1986), hlm. 73-74

${ }^{23}$ Muhaimin. 2004. hlm. 138 
orang lain, tetapi berdasarkan dari kemauan sendiri. Dalam belajar terkandung tujuan menambah pengetahuan. "Intrinsic motivations are inherent in the learning situation and meet pupil need and purposes".

b. Motivasi Ekstrinsik

Jenis motivasi ini juga timbul sebagai akibat pengaruh dari luar diri individu. Apakah karena adanya ajakan, paksaan dari orang lain sehingga dengan kondisi yang demikian akhirnya ia mau melakukan sesuatu.

Untuk dapat membangkitkan motivasi belajar siswa, guru hendaknya berusaha dengan berbagai cara guna perbaikan. Berikut ini ada beberapa cara membangkitkan motivasi ekstrinsik dalam rangka menumbuhkan motivasi instrinsik: 1). Kompetisi (persaingan, guru berusaha menciptakan persaingan diantara siswanya guna meningkatkan prestasi belajar). 2). Pace making, pada awal KBM guru hendaknya menyampaikan trik pada siswa. 3). Tujuan yang jelas dalam mencapai pembelajaran. 4). Mengadakan penilaian, pada umumnya siswa mau belajar dengan tujuan mendapat nilai yang baik. ${ }^{24}$

Dalam pembelajaran ada beberapa bentuk motivasi yang dapat digunakan oleh seorang guru guna mempertahankan minat peserta didik terhadap bahan pelajaran yang diberikan agar selalu aktif dan antusiasme siswa. Bentuk-bentuk motivasi tersebut adalah: 1). Memberi Angka, 2). Hadiah, 3). Pujian, 4). Memberi Tugas dan 5). Hukuman.

Dari paparan di atas peneliti dapat menyimpulkan bahwa penerapan strategi aktif learning di MI Syarifuddin dapat meningkatkan motivasi belajar siswa karena pada dasarnya

24 Moh.Uzer Usman, Menjadi Guru Profesional (Bandung: Remaja RosdaKarya, 1992), hlm.24-25 
para siswa mengalami perubahan dari yang kurang semangat, malas, bisan dengan pembelajaran menjadi aktif, tertarik dengan pembelajaran, antusius serta mengajukan pertanyaan kepada guru dan teman kelas yang sedang presentasi yang dilakukan di depan kelas meskipun masih ada sebagian yang motivasinya tidak meningkat dan juga ada yang motivasi menetap.

3. Faktor pendukung dan penghambat dalam penerapan strategi pembelajaran aktif dalam meningkatkan motivasi belajar Aswaja siswa di MI Syarifuddin.

Setiap aktivitas dalam upaya mengembangkan dibidang keilmuan senantiasa dipengaruhi oleh beberapa faktor pendukung dan penghambat demikian juga halnya dalam penerapan strategi aktif learning dalam meningkatkan motivasi belajar siswa SKI di MI Syarifuddin ada beberapa faktor pendukung dan penghambat diantaranya:

Faktor pendukung penerapan strategi aktif learning diantaranya yaitu:

a. Fasilitas lengkap, dalam pembelajaran kalau tidak didukung dengan fasilitas yang lengkap akan menghambat pembelajaran tersebut, contoh dari fasilitas adalah RPP, LCD PROYEKTOR, SOUND, TV DLL. di MI Syarifuddin sudah mempunyai fasilitas lengkap meskipun tidak semua kelas dilengkapi oleh fasilitas tersebut.

b. Profesionalisme dan semangat guru, di MI Syarifuddin kusus pada mata pelajaran Aswaja yang diajar oleh bapak Syakur, dari hasil observasi peneliti dalam pembelajaran Aswaja bahwa bapak Syakur sudah termasuk guru yang berprofesional dan bersemangat karena waktu siswa diajar oleh bapak Syakur mereka sangat tertarik dan bersemangat 
meskipun masih ada sebagian yang masih ramai-ramai sendiri.

c. Minat belajar siswa, dalam pelaksanaan aktif learning minat belajar siswa adalah faktor yang penting di sini ialah haru skembali kepada diri siswa masing-masing, akan tetapi minat belajar mereka bisa meningkat dengan melalui oleh bimbingan oleh guru masing-masing.

Hal ini sesuai dengan teori yang dipaparkan sebagai berikut:

a. Guru sebagai pendidik yang Profesional

Guru adalah pengajar yang mendidik secara profesional. Tidak hanya mengajar bidang studi yang sesuai dengan keahliannya, akan tetapi juga menjadi pendidik generasi muda bangsanya. Sebagai pendidik, ia memusatkan perhatian kepada kepribadian siswa, khususnya emansipasi dari siswa. Sebagai guru pengajar, ia bertuga mengelola kegiatan belajar siswa di sekolah.

b. Penyediaan Alat Peraga/Media

Dalam kegiatan belajar mengajar maka alat atau media sangat diperlukan agar supaya dapat menunjang tercapainya tujuan pendidikan. Media ini harus diupayakan selengkap mungkin agar segala aktivitas mengajar dapat dibantu melalui bantuan dari media tersebut. Sehingga guru tidak terlalu banyak mengeluarkan tenaga dalam penyampaian materi atau bahan pelajaran yang akan disampaikan.

c. Kelengkapan Kepustakaan

Kepustakaan sebagai kelengkapan dalam menunjang keberhasilan pengajaran, hendaknya diisi dengan berbagai buku yang relevan sebagai upaya guna pengayaan terhadap pengetahuan dan pengalaman siswa. Semakin banyak siswa 
yang membaca buku maka akan semakin banyak pula pengetahuan yang dimiliki sehingga wawasan siswa terhadap materi pelajaran. Begitupun semakin bertambah, dan pada akhirnya tujuan pengajaran akan mudah tercapai secara efektif.

Dari paparan di atas maka peneliti menemukan bahwa Faktor pendukung yang peneliti menemukan di MI Syarifuddin adalah sesuai dengan paparan teori yaitu ada fasilitas lengkap, profesionalisme guru namun pula hal yang baru peneliti meneukan adalah minat belajar siswa dan jam waktu pelajaran.

Selain itu ada juga faktor penghambat dalam penerapan strategi aktif learning ialah Faktor penghambat penerapan strategi aktif learning yaitu:

a. Siswa masih enggan dalam menyampaikan pendapatnya, ini bukan semua siswa akan tetapi hanya beberapa saja, hal ini bisa jadi karena mereka masih memiliki rasa malu dan belum terbiasa berbicara di depan kelas.

b. Latar belakang bagi setiap siswa juga bisa menjadi penghambat dalam pelaksanaan aktif learning, karena dari latar belakang yang berbeda secara akan mempengaruhi kemmapuan mereka, ada yang sulit untuk keluarga berpendidkan maka mereka lebih terbuasa dengan belajar dan senang untuk belajar. Ada juga yang dari keluarga petani maka mereka ada pula yang tidak tertarik bahkan tidak mau belajar karena mereka tidak terbuasa.

c. Waktu pembelajaran, waktu sangat berpengaruh dalam pembelajaran misal kalau pembelajaran yang mulainya diwaktu pagi para siswa segar jadi guru menyampaikan apa-apa siswa lebih mudah untuk menerima. Namun kalaupun waktu pembelajaran yang mulainya disiang hari maka siswa lebih sulit karena jam siang biasanya membuat siswa mengantuk dan tidak 
semangat belajar berkurang dan juga karena sudah banyak menerima materi yang disampaikan sebelumnya dari pagi selama pembelajaran berlangsung.

d. Fasilitas dalam pelaksanaan pembelajaran seorang harus menyiapkan semua fasilitas yang terlait dengan pembelajaran tersebut misal dalam pembelajaran Aswaja.

\section{Kesimpulan}

Berdasarkan paparan data dan analisis yang telah dikemukakan, kesimpulan yang dapat diambil dari penerapan Strategi Pembelajaran Aktif Dalam Meningkatkan Motivasi Belajar Siswa Aswaja di MI Syarifuddin

1. Penerapan strategi pembelajaran aktif dalam meningkatkan motivasi belajar SKI siswa di MI Syarifuddin.

Dalam melaksanakan kegiatan belajar mengajar Aswaja di MI Syarifuddin, Guru sebagai uswah melalui pendekatan belajar aktif (active learning strategy) yang terdidri atas metode Diskusi, jigsaw, index card match, drill. Tanya jawab, hafalan juga demonstrasi. Dalam penerapan pendekatan metode tersebut, guru menyesuaikan dengan jenis sifat bahan serta materi pembelajaran, situasi dan kondisi dalam proses belajar mengajar, cara penerapan strategi belajar aktif. dalam pembelajaran Aswaja di MI Syarifuddin, dalam menggerakkan siswa agar belajar aktif.

2. Peningkatan motivasi belajar SKI siswa di MI Syarifuddin.

Penerapan strategi aktif learning di MI Syarifuddin juga dapat meningkatkan motivasi belajar siswa karena sesungguhnya para siswa mengalami perubahan hal ini ditandai dengan siswa suka dengan pembelajaran, senang, tidak malas, tidak bosan selalu ada timbal balik komunikasi antara guru dan siswa, juga selalu ada yang bertanya kepada guru dan kepada teman yang sedang 
presentasi di depan kelas kendatipun masih ada sebagian yang motivasinya tidak meningkat dan juga ada yang motivasinya menetap.

3. Faktor pendukung dan penghambat dalam penerapan strategi pembelajaran aktif dalam meningkatkan motivasi belajar SKI siswa di MI Syarifuddin.

Beberapa di antara faktor-faktor pendukung ialah adanya sarana dan sumber belajar yang memadai, minat belajar siswa yang tinggi serta semangat, jam waktu pembelajaran dan serta profesionalisme guru Aswaja dalam membimbing para siswa. Sedangkan faktorfaktor penghambat antara lain adanya sebagian siswa yang masih enggan guna mengemukakan pendapatnya, jam waktu pembelajaran, fasilitas yang tidak mendukung serta latar belakang siswa yang berbeda.

\section{Daftar Pustaka}

Ahmad Salim. Manajemen Pendidikan Karakter di Madrasah. Tarbawi: Jurnal Keilmuan Manajemen Pendidikan. December 2019.

Ahmadi Dan Widodo S. 1991. Belajar Dan Pembelajaran. Jakarta:Rineka Cipta.

As'ad, Mahrus Dkk. 2009. Ayo Mengenal Sejarah Kebudayaan Islam. Jakarta: Erlangga.

A.M, Sardiman. 1986. Interaksi \& Motivasi Belajar Mengajar. Jakarta: Pt. Raja Grafindo Persada.

Al- Qur'an Dan Terjemahnya. 2012. Bandung : Syaamil Quran.

Burga, Muhammad Alqadri. Hakikat Manusia Sebagai Makhluk Pedagogik. Journal of Islamic Education and Teacher Training, ISSN 2657-2362. Vol 1 No 1 (2019). 
Direktorat Jendral Pendidikan Islam. 2010. Model Silabus Dan Rencana Pelaksanaan Pembelajaran Sejarah Kebudayaan Islam. Jakarta: Kementrian Agama Republik Indonesia.

Djaali. 2009. Psikologi Pendidikan. Jakarta: Bumi Aksara.

Dkk, Rosjidan. 2003. Belajar Dan Pembelajaran. Malang: Departemen Pendidikan Nasional Universitas Negeri Malang Fakultas Ilmu Pendidikan.

Hamalik, Oemar. 2001. Proses Belajar Mengajar. Jakarta: Pt. Bumi Aksara.

Hartono. 2005. Suatu Strategi Pembelajaran Berbasis Student, Disampaikan Seminar Nasional

Munjin Nasih, Ahmad Dan Nur Kholidah, Lilik. 2009. Metode Dan Teknik Pembelajaran Pendidikan Agama Islam,. Bandung: Refika Aditama.

Machmudah, Umi Dan Wahab, Abdul. 2008. Active Learning Dalam Pembelajaran Bahasa Arab. Malang, Uin-Malang Press.

Mahsun, Moch \& Danish Wulydavie Maulidina. 2019. “Konsep Pendidikan Dalam Kitab Ta'limul Muta'allim Karya Syekh AlZarnuji Dan Kitab Washoya Al-Aba' Lil-Abna' Karya Syekh Muhammad Syakir". Bidayatuna: Jurnal Pendidikan Guru Mandrasah Ibtidaiyah, 2 (2), halaman 44-77

Mukhtar. 2009. Orientasi Baru Supervise Pendidikan,. Jakarta: Gunung Persada Press.

Rachman, Rio Febriannur. 2019. “Implementasi Kebijakan Pusat Konseling Anak Dan Remaja Di Surabaya". Al-Tazkiah: Jurnal Bimbingan Dan Konseling Islam, 8(2), 77-91

Peraturan Menteri Agama Republik Indonesia Nomor 2 Tahun 2008 Tentang Standar Kompetensi Lulusan Dan Standar Isi Pendidikan Agama Islam Dan Bahasa Arab Di Madrasah.

Purwanto, Ngalim. 2004. Psokologi Pendidikan. Bandung: Pt. Remaja Rosdakarya.

Sutadipura, Balnadi. 1997. Aneka Problema Keguruan. Bandung: Angkasa.

Silbermen, Terjamahan Dari Active Learning Strategy : 101 Strategies To Teach Aay Subject. Terjamahan : Raisal Muttaqin. 2004. Boston: Allyn Balcon. 
Siti Solehah. Pengaruh Media Pembelajaran Berbasis Aplikasi Pada Smartphone Android Dilengkapi Game Twoplayer Terhadap Hasil Belajar Kognitif Siswa. journal.unnes.ac.id

Semiawan, Conny. 1985. Pendekatan Kreampilan Proses: Bagaimana Mengaktifkan Siswa Dalam Belajar. Jakarta: Pt Gramedia.

Sukandi. 2003. Belajar Aktif Dan Terpadu, Apa, Mengapa Dan Bagaimana. Surabaya, Duta Graha Pustaka.

Uhbiyati, Nur. 1999. Ilmu Pendidikan Islam. Bandung: Pustaka Setia.

Uzer Usman, Moh. 1999. Menjadi Guru Profesional. Bandung :Pt. Remaja Rosdakarya.

Uao, Hamzah B. 2007. Model Pembelajaran: Menciptakan Proses Belajar Mengajar Yang Efektif Dan Kreatif. Jakarta: Bumi Aksara.

Usman, Moh.Uzer, 1992. Menjadi Guru Profesional. Bandung: Remaja Rosda Karya.

Undang- Undang Republik Indonesia Tentang Sistem Pendidikan Nasional. 2003. Jakarta: Pt Kloang Klede Putra.

Uno,Hamzah B. 2009. Teori Motivasi dan Pengukurannya Analisis di Bidang Pendidikan. Jakarta: PT Bumi Aksara.

Yasin, A. Fatah. 2008. Dimensi-Dimensi Pendidikan Islam. Malang: UinMalang Press.

Zaini, Hisyam Dkk. 2008. Strategi Pembelajaran Aktif. Yogyakarta: Pustaka Insani Madani. 